\title{
Analýza bezpečnostní politiky během Mistrovství světa ve fotbale 2014 v Braźlii
} Analysis of security policy during the FIFA World Cup 2014 in Brazil

\author{
Jakub Šiman, Josef Smolík \\ Fakulta sociálních studií Masarykovy univerzity v Brně
}

\begin{abstract}
Abstrakt
Předkládaná případová studie analyzuje bezpečnostní politiku mistrovství světa ve fotbale 2014 $\checkmark$ Brazílii. Studie si klade za cíl predstavit největši rizika spojená s pořádáním akce takového rozsahu a analyzovat strategický př́stup Brazílie k zajištění bezpečnosti během šampionátu. Mezi největší bezpečnostní rizika šampionátu byly řazeny oblasti jako terorismus, kriminalita, sociální protesty, divácké násilí a chuligánství, kybernetické hrozby nebo zdravotní rizika. Práce se zároveň zaměřuje i na samotný průběh mistrovství a na důsledky, které s sebou príneslo.
\end{abstract}

\begin{abstract}
The case study analyzes the security policy of FIFA 2014 World Cup in Brazil. This study aims to present the greatest risks associated with organizing events of such magnitude and analyze strategic Brazils approach to ensure security during the championship. Among the biggest security risks of the championship were classified areas as terrorism, crime, social protests, spectator violence and hooliganism, cyber threats and health hazards. The paper also focuses on the actual process of championships and the consequences which brought about.
\end{abstract}

Klíčová slova: Bezpečnostní politika, Mistrovství světa 2014, fotbal, chuligánství, terorismus, kriminalita, protesty, nepokoje, Brazílie.

Keywords: Security policy, World Cup 2014, football, hooliganism, terrorism, criminality, protests, riots, Brazil.

\section{ÚVOD}

Studie si klade za cíl analyzovat uplatněnou bezpečnostní politiku během Mistrovství světa ve fotbale, které se uskutečnilo v Brazilské federativní republice (dále jen Brazílie) v roce 2014. Přesněji se jednalo o období mezi 12. červnem až 13. červencem.

Zajištěním bezpečnosti během velkých sportovních událostí (events/mega-events) se v minulém století strategická a bezpečnostní studia zabývala jen okrajově. Důležitým milníkem byl rok 1972 a útok palestinské skupiny „Black September“ na izraelské sportovce během olympiády v Mnichově. Nicméně ještě větší dopad měly na vnímání sektorů bezpečnosti až události z 11. září 2001, kdy došlo $\mathrm{k}$ únosu 4 civilních letadel. Tři z nich byla následně použita $\mathrm{k}$ teroristickým útokům na Světové obchodní centrum v New Yorku a sídlo Ministerstva obrany USA (Pentagon). Čtvrté letadlo se po souboji posádky a útočníků zřítilo v neobydlené oblasti. Po těchto událostech došlo ke změnám $v$ percepci bezpečnosti jako takové.

Během studené války se koncept bezpečnosti poutal především ke státním hranicím jednotlivých států. $\mathrm{S}$ ukončením bipolárního rozdělení světa a dalšími změnami v mezinárodním bezpečnostním prostř̌edí se však koncept bezpečnosti musel rozšiřit, aby byl schopen reagovat na nové aktéry či hrozby. Musel se změnit přístup k tomu, jak zajistit bezpečnost. Státy již nemohly spoléhat na to, že př́padný útok bude veden na jejich hranicích. Útočníci nyní mohli udeřit kde- 
koliv. Kvůli tomu tak muselo náležitě dojít i ke změně bezpečnostních opatření během plánování a pořádání velkých (nejen) sportovních akcí (Boyle, Haggerty 2009).

Události, jako jsou olympijské hry či mistrovství ve fotbale, se těší zájmu celého světa a pořadatelské země a města se musí vyrovnat s mnoha bezpečnostními fenomény, které s sebou akce takovéhoto rozsahu nesou.

Mistrovství světa ve fotbale, které se uskutečnilo v Brazílii, bylo v mnoha ohledech jedinečné. Tato práce si klade za cíl zanalyzovat bezpečnostní rizika a hrozby, které doprovázely celou událost, a zároveň také popsat opatření a způsoby jejich eliminace. V českém prostředí v současné době neexistuje práce, která by komplexně hodnotila bezpečnostní prostředí v Brazílii v kontextu Mistrovství světa ve fotbale 2014.

\section{METODIKA}

Předkládaný článek je z pohledu metodologie kvalitativním výzkumem, přesněji pak př́ípadovou studií a má spíše deskriptivní charakter. Zaměřuje se na detailní popis a rozbor jednoho př́padu, kterým je pořádání Mistrovství světa ve fotbale v roce 2014 v Brazílii. Práce se snaží zachytit co největší počet proměnných, které ovlivňují plánování a pořádání tak velké akce. Dle Hendla (2005) se předpokládá, že porozumění jednotlivému př́ípadu vede k pochopení ostatních a podobných př́padů. Hendl rozděluje případové studie na několik kategorií podle sledovaných jevů. Tato práce ze své podstaty zahrnuje hned několik těchto oblastí, jež se v ní navzájem překrývají.

- Studium organizací a institucí - především se jedná o změny v přístupech $\mathrm{k}$ bezpečnosti státních (např. složky policie a armády) i nestátních organizací (např. bezpečnostní agentury, neziskové organizace bojující za lidská práva) před zahájením šampionátu.

- Zkoumání událostí, rolí a vztahů - zkoumání se týká především období, kdy samotné mistrovství probíhalo. Nicméně pro pochopení a zasazení do širšího kontextu je třeba věnovat se i událostem, které závěrečnému turnaji předcházely, i těm, které po něm následovaly. $V$ tomto ohledu tak práce mapuje období od roku 2007 až do současnosti.

- Č́stečně až okrajově pak práce zahrnuje i studium sociálních skupin, jako jsou zaměstnanecké kolektivy zasahujících bezpečnostních složek a orgánů státní správy nebo demonstrující skupiny obyvatelstva. V práci lze též nalézt i pasáže, které by bylo možné zahrnout do další Hendlem definované kategorie, a tou je studium komunit (např. chudinských čtvrtí).

K získávání dat byla využita obsahová analýza dokumentů a odborných studií z oblasti bezpečnostních a strategických studií, ale i z jiných oborů souvisejících s problematikou pořádání akcí podobného rozsahu, dále bylo využito i publicistických a zpravodajských pramenů. Pro práci jsou stěžejní především následující dokumenty. Důležitým zdrojem je text s názvem $O S A C$ Assessment: 2014 FIFA World Cup od Ministerstva zahraničí Spojených států amerických, konkrétně od Bezpečnostní rady pro zahraniční záležitosti (The Overseas Security Advisory Council, dále jen OSAC). Jedná se o hodnocení bezpečnostních hrozeb před Mistrovstvím světa a během něj včetně sady doporučení pro návštěvníky Brazílie.

Práce čerpá také z dokumentu Security Governance and Sport Mega-events: Towards an Interdisciplinary Research Agenda, jehož autory jsou Richard Giulianotti a Francisco Klauser. Jedná se o sociální vědce, kteři se problematice pořádání velkých sportovních akcí věnují dlouhodobě.

Z internetových zdrojů je třeba zmínit World Cup Portal, který byl spravován brazilskými vládními orgány. Dalšími internetovými zdroji jsou nejčastěji zpravodajské servery.

Giulianotti a Klauser (2010) identifikují základní 3 oblasti bezpečnostních hrozeb a rizik, která doprovázejí velké sportovní akce typu mistrovství světa nebo olympiády. První je hrozba teroristického útoku, druhou je divácké násilí a násilí spojené s politickou př́slušností a poslední rizikovou oblastí je městská kriminalita, chudoba a sociální stratifikace.

Brazilské prostředí je velmi specifické. Právě kvůli jedinečnosti prostředí se autor rozhodl koncept Giulianottiho a Klausera rozššřit o některé další oblasti, případně jednotlivé kategorie 
rozmělnit. Jedná se o propojení př́stupu zprávy OSAC Assessment: 2014 FIFA World Cup a konceptu Giulianottiho a Klausera. V práci je tak využito dělení hrozeb na celkem 6 kategorií (místo původních 3):

1. Hrozba teroristického útoku

2. Kriminalita

3. Divácké násilí a chuligánství

4. Sociální nepokoje a demonstrace

5. Hrozba kybernetického útoku

6. Zdravotní rizika

Všechny zmíněné hrozby jsou nejdřive stručně představeny a poté zasazeny do kontextu brazilského prostředí.

Co se týče důsledků šampionátu, hovoříme o tzv. bezpečnostním odkazu. Giulianotti a Klauser (2010) definují bezpečnostní odkaz jako soubor bezpečnostních opatření, která mají svým fungováním dopad na společnost i po skončení velké sportovní události. Autoři vytvořili typologii 6 hlavních oblastí, ve kterých lze bezpečnostní odkaz spatřovat.

1. Bezpečnostní technologie, které jsou zavedeny kvưli sportovní události a které zůstávají funkční i po ukončení akce. Př́kladem jsou kamerové systémy v centrech měst.

2. Nové bezpečnostní postupy, které jsou uplatňované během zajištování bezpečnosti. Například větší provázanost státních a soukromých subjektů zabývajících se bezpečností.

3. Nové politiky a zákony zajištující bezpečnost v průběhu událostí.

4. Změny v uspořádání společnosti s přihlédnutím $\mathrm{k}$ bezpečnosti - vytěsnění obyvatel $\mathrm{z}$ veřejných prostranství či oblastí, kde se má akce pořádat.

5. Změny v mezilidských a sociálních vztazích - příkladem by mohl být změněný přistup obyvatel $\mathrm{k}$ policii v důsledku uplatňované bezpečnostní strategie.

6. Urbánní rozvoj a přestavba, která má spojitost se sekuritizací - vyklízení a rekultivace slumů.

\section{Bezpečnostní hrozby a rizika Mistrovství světa}

Výkonný výbor organizace FIFA rozhodl o Brazílii jako pořadatelské zemi již v roce 2007 na svém ř́ijnovém zasedání v Curychu. Brazílie byla jediným kandidátem, jelikož druhý kandidát (Kolumbie) se rozhodl předčasně odstoupit. Výběr pořadatelské země tak byl víceméně formalitou. Přesto však panovalo jisté napětí ohledně schopností Brazílie organizovat událost takového rozsahu. Největšími problémy byla nedostatečná infrastruktura, vysoká kriminalita nebo nedostatečné služby pro budoucí návštěvníky (např. ubytovací kapacity hotelů), ze sportovního hlediska byla největším zdrojem obav stavba stadionů. Brazílie neměla $v$ době přidělení pořadatelství ani jeden stadion, který by splňoval regule organizace FIFA. Stále však do zahájení šampionátu zbývalo 7 let. Podle organizátorů z jihoamerické země to byl dostatečný čas (Sport 2007).

Brazílie nicméně usilovala i o pořadatelství dalších velkých sportovních akcí (např. Pohár konfederace $\mathrm{v}$ roce 2013). V kontextu této práce je třeba zmínit především Letní olympijské a paralympijské hry, které se budou konat v roce 2016 v Riu de Janeiru. Brazílie totiž od roku 2007 přizpůsobovala svou bezpečnostní politiku těmto událostem a často se tak jednotlivá opatření mohou překrývat svou účinností. Kuprríkladu výstavba nové infrastruktury a zlepšení té stávající představuje opatření, které sice bylo provedeno před mistrovstvím světa ve fotbale, ale zároveň bude mít vliv i na organizaci her $\mathrm{v}$ roce 2016.

\subsection{Hrozba teroristického útoku}

„Terorismem se rozumí kriminální činy zaměřené proti civilistům, spáchané s úmyslem způsobit smrt nebo závažné tělesné zranění, či zmocnění se rukojmí, s účelem vyprovokovat stav zastrašení v široké veřejnosti nebo ve skupině lidí nebo specificky zaměřené skupině lidí, zastrašit populaci nebo donutit vládu či mezinárodní organizaci, aby něco učinila nebo aby se zdržela nějakého aktu“ (Smolík, Šmíd 2010: 116). 
Zlomovými body pro plánování velkých sportovních akcí byly roky 1972 a 2001 . Na mnichovské olympiádě se v roce 1972 udál bezprecedentní teroristický útok na izraelské sportovce a funkcionáře, který sledoval v takřka přímém přenosu celý svět. Právě pokrytí situace médii stálo za tím, že si teroristé byli schopni uvědomit, jak obrovský potenciál mají velké sportovní události pro šíření jejich poselství. Olympijské hry navíc díky sponzorům a mezinárodním korporacím představují symbol západního kapitalismu. V roce 1972 se v této souvislosti objevily i názory, že olympijské hry ztratily svou „nevinnost“. Od roku 1972 se tak zajištění bezpečnosti během sportovních akcí dostávalo do většího povědomí. Cílem teroristů ale nebyli jen sportovci. Důkazem je rok 1996 a bombový útok na Olympiádě v Atlantě. Dalekosáhlejší následky mělo však již zmiňované 11. záŕí 2001, které ukázalo, jak velké ztráty může terorismus způsobit. Po tomto útoku došlo dokonce ke zrušení několika dalších sportovních akcí a mnoho sportovců dokonce odmítlo jezdit na závody a utkání (Taylor, Toohey 2007).

Následkem útoků je i fakt, že náklady na pořádání sportovních akcí toho největšího charakteru (olympijské hry, mistrovství světa) se v podstatě stále zvedají a nejvíce roste podíl výdajů na zajištění bezpečnosti.

Dle OSAC nejsou v Brazílii známy žádné domácí teroristické skupiny a země ani není cílem radikálních hnutí. Nicméně Ministerstvo zahraničí Spojených států uvádí, že kvůli povaze Mistrovství světa ve fotbale byl teroristický útok možný. Zájem, jaký ve světě o tento šampionát panoval, by mohl teroristické skupiny prrilákat. Mistrovství by dle expertů mohlo upoutat i pozornost „osamělého vlka“, který by mohl udeřit podobně jako například v roce 2013 útočníci na Maratonu v Bostonu. Osamělého radikalizovaného útočníka se nejvíce obávala i brazilská vláda.

Přestože není žádná známá teroristická organizace přítomna přímo v Brazílii, i tak je země částečně terorismem ohrožena. Jedná se ale spíše o dřive zmíněný organizovaný zločin spojený s některými prvky terorismu. Př́kladem může být narkoterorismus (spojený s pašováním drog a zbraní) v sousedních zemích, jako je Kolumbie. Nejohroženější oblastí je tzv. „Tri-Border Area“, ležící na jihozápadě země u hranic s Argentinou a státem Paraguay (Breslin 2013).

\subsection{Kriminalita}

Brazílie je všeobecně známá vysokou mírou městské kriminality. Přestože země za posledních několik dekád prošla velkým vývojem a demokratizací, stále je mnoho oblastí, které jsou specifické spíše pro autoritativní režimy - omezování lidských práv, sociální a ekonomická nerovnost obyvatelstva nebo jen částečná svoboda tisku. Důležitým důsledkem tranzice je právě i zvýšená kriminalita a rozvoj organizovaného zločinu. Násilná kriminalita rostla od začátku 80 . let hlavně ve velkých metropolích, jakými jsou Sao Paulo nebo Rio de Janeiro, a především pak v okrajových chudinských čtvrtích - slumech. OSN slum (favelu) definuje jako chudou čtvrt bez vody a základních služeb se špatně postavenými a přelidněnými přístřešky. Obyvatele slumů tvoří nejchudší vrstvy obyvatel, kteří jsou velmi často nezaměstnaní, proto je také v těchto oblastech organizovaný zločin nejaktivnější. Přepadení, vraždy, pašování drog nebo únosy lidí jsou zde na denním pořádku. Např́íklad v roce 2012 prripadalo v Brazílii na 100000 obyvatel více jak 25 vražd. Pro srovnání v České republice to byla za stejné období 1 vražda (Adorno 2013).

Turisté a návštěvníci šampionátu byli upozorňováni na zvýšenou míru kriminality v Brazílii. Největší „kriminálni“ hrozbou byl tzv. příležitostný pouliční zločin, který zahrnuje kapesní krádeže, loupežná přepadení, krádeže aut, vykrádání hotelových pokojů a podvody s kreditními kartami. V Brazílii je oblíbenou technikou tzv. card skimming - tedy využívání čtecích zařízení ke skenování magnetických proužků karet a následné falšování těchto karet. Zvláštní případ násilné kriminality poté představuje tzv. relampago express (bleskový únos), kdy je obět přepadena během výběru peněz z bankomatu a pod výhružkou použití zbraně je donucena vybrat hotovost i z jiných bankomatů, kam ji útočníci zavedou, oběti jsou ale nakonec propuštěny. Jako nejrizikovějši oblasti byly označovány pláže, hotely, diskotéky a noční podniky, bary a podobná místa, kde se střetává velký počet lidí, zejména turistů. Zvýšené riziko platilo i pro místa, kam se uchylují movitější obyvatelé, jako např́ílad luxusní restaurace atd. Občané byli také varováni, aby pokud možno necestovali 
jako jednotlivci a cestovanou trasu si vždy dopředu naplánovali. Úřady důrazně nedoporučovaly cestovat skrze slumy (OSAC Assessment 2014).

\subsection{Sociální nepokoje a demonstrace}

Nepokoje a protivládní protesty v Brazílii nejsou z dlouhodobého hlediska obvyklé (poslední výrazné protivládní protesty se datují k roku 1992). Ani po oznámení pořadatelství mistrovství světa se nezdálo, že by se tento trend měl měnit. I přes několik nesouhlasných hlasů se tehdy demonstrace nezdály jako reálná hrozba pro bezpečnost během závěrečného turnaje šampionátu. Změna přišla během Poháru konfederace, který Brazílie pořádala $v$ roce 2013. Vše začalo jako lokální demonstrace reagující na zvýšení jízdného městské hromadné dopravy ve městě Sao Paulo. Během několika dní se však na základě těchto menších protestů aktivizovalo mnohem větší množství lidí, kteří vyráželi do ulic měst. Velkou roli sehrály sociální sítě, skrze které se lidé domlouvali. Na tuto skutečnost zareagovala i policie a snažila se kyberprostor lépe monitorovat. Tématem protestních akcí již nebylo zvýšené jízdné, ale korupce, školství, nízká úroveň a nedostupnost zdravotní péče a hlavně výdaje spojené s pořádáním Poháru konfederace a následně i mistrovství světa ve fotbale.

V prvotních fázích byly protesty většinou poklidné a nenásilné, ale objevily se i případy výtržnictví, vandalismu a rabování. Státní orgány Brazílie na to reagovaly povoláním policejních a armádních složek. S postupem času napětí eskalovalo a docházelo k stále častějším střetům mezi demonstranty a policií. Jak je zmíněno výše, metody brazilské policie jsou dosti nevybíravé. Za své jednání byla brazilská policie kritizována různými mezinárodními organizacemi, které se zabývají dodržováním lidských práv. Například Amnesty International kritizovala policejní brutalitu a užívání donucovacích prostředků na demonstranty a zároveň i šikanu ze strany policie, jejíž členové zneužívali zákony k zadržování protestujících. Dalším tématem demonstrantů se tak stal i boj za lidštější policii.

Brazilské úřady označily za hlavní viníky násilností členy anarchistické skupiny Black Bloc, kteří měli infiltrovat demonstrace. Účastníci protestů se od organizace Black Bloc distancovali. Zachycením řádění př́iznivců této organizace vytvářela média obraz o demonstracích v Brazílii, který se však nemusel vždy shodovat s realitou (OSAC Assessment 2014).

Zvláštním př́ípadem demonstrací se staly tzv. rolezinhos, v překladu „malé procházky“. Jednalo se o dopředu domluvené schůzky (nejčastěji teenagerů) v nákupních stř̌ediscích ve velkých brazilských městech. Účastníci pak procházeli stř̌ediskem a vyvolávali hesla o konzumu či protivládní slogany. Doprovázeni byli hlasitou hudbou z přenosných zařízení. Svým chováním často obtěžovali jednotlivé zákazníky a zaměstnance center. Počet účastníků mohl dosahovat i stovek až tisíců jedinců. Ačkoli se jednalo o nenásilnou formu protestu, policie neváhala k rozehnání těchto shromáždění využít slzný plyn a střelbu gumových projektilů (OSAC Assessment 2014).

Brazílie se však nepotýkala jen s nepokoji a demonstracemi. Dủležitou roli hrály i stávky zaměstnanců. Jedna z nejvýznamnějších se odehrála v Riu de Janeiro 12. července 2013. Jednalo se o stávku, které se $\mathrm{v}$ celé Brazílii zúčastnilo deset tisíc zaměstnanců. Ti zablokovali některé prrístavy a silnice. Školy a některé instituce zůstaly zavřené. Stávku svolaly odbory a jejím cílem bylo zlepšení pracovních podmínek a veřejných služeb. Stávku doprovázelo několik demonstrací. Ačkoliv byly demonstrace poklidnější než dříve, stejně došlo k několika střetům mezi policií a davem (BBC 2013).

Situace se částečně uklidnila díky opadnutí zájmu medií i s přislíbením reforem ze strany brazilské vlády a nepodpoření návrhu změny ústavy, která měla omezit pravomoci prokurátorů, a tím ztížit i například trestání korupce. K protestním akcím se přidali i odboráři a ti přinesli další témata - zkrácení pracovního týdne ze 44 hodin na 40 nebo růst penzí (Česká televize 2013).

Nepokojů se zúčastnily miliony lidí, několik lidí přišlo během potyček o život a mnoho lidí bylo zraněno. $Z$ demonstrací se stal nástroj, skrze který se díky vysoké míře medializace často snažily brazilské organizace a skupiny zviditelnit. Velký zájem medií však vedl i k tomu, že se z nepokojů, demonstrací a stávek staly jedny z nejdiskutovanějších hrozeb pro nadcházející mistrovství světa. 


\subsection{Divácké násilí a chuligánství}

„Fotbaloví chuligáni (hooligans) se identifikují se ,svými‘ týmy a využívají hracích dnů jako př́ležitosti ke konfrontaci s jinými skupinami fanoušků či chuligánů s cílem co nejvíce ovládat divácký sektor, či dokonce hrací plochu. Dnes je "hooliganism“ sociálně nebezpečný tím, že se projevuje i mimo fotbalové stadiony, kde mimo předpokládaný dohled policie vyvolává bitky mezi fanoušky soupeřících týmů. Tím se zásadně liší od fotbalových diváků (nezaujatí pozorovatelé, objektivně hodnotící hru i jednotlivé výkony) a fanoušků (zaměřenost na výhru oblíbeného týmu či hráče). Fotbalové chuligánství je tak subkulturou přerůstající některými svými projevy v kontrakulturu. Necílí totiž k čestnému soutěžení na základě principů fair play, nýbrž k produkci chování, které lze ze společenského hlediska označit jako deviantní, směřující proti běžně uznávaným společenským hodnotám a normám“ (Sekot 2008: 159).

Brazílie se tedy před závěrečným turnajem musela vyrovnat se dvěma základními problémy. Prvním je zajištění bezpečnosti během zápasů přímo na stadionu. Pokud by došlo k násilnostem během utkání, ohrozilo by to zdraví nejen diváků na tribunách a v útrobách stadionu, ale i realizačních týmů a hráčů na hřišti. Ohroženy by byly samozřejmě i zasahující složky a civilní zaměstnanci.

Druhým problémem je chuligánství jako takové, protože to se přesunulo mimo stadiony a př́mý dohled státních orgánů. Skupiny hools se již tolik nepoutají k fotbalu jako hře. Hlavním prvkem je násilí a adrenalin z potyček, jež si jednotlivé skupiny domlouvají. K předem domluveným střetům dochází často mimo město a mimo herní dny, tudíž jsou pro policii hůře odhalitelné. Důležité je ještě rozdělit chuligány na domácí a zahraniční, kteří do země kvưli mistrovství světa přicestují. Domácí hooligans jsou spjati především s brazilskou 1. fotbalovou ligou - Campeonato Brasileiro Série A a jejími účastníky. Tuto ligu v současné době tvoří 20 družstev.

Brazílie v minulosti podnikla již několik kroků k omezení násilností spojených s fotbalem a chuligánstvím. Jedním z nich je kontroverzní zákon z roku 2003, který zakazoval prodej alkoholických nápojů na fotbalových stadionech. Tento zákon však musel být po jednání Brazílie s organizací FIFA upraven jiným zvláštním zákonem, nebot FIFA vyžadovala prodej piva během zápasů. Byla tedy zavedena výjimka a během poháru konfederace a mistrovství světa si fanoušci na stadionech mohli pivo zakoupit. FIFA to komentovala tím, že pivo a mistrovství světa ve fotbale $\mathrm{k}$ sobě patří (OSAC Assessment 2014, Český rozhlas 2012).

Jako nejrizikovější se ze zahraničních chuligánů nejčastěji zmiňovali ti evropští z Německa, Anglie či Nizozemí. Největší hrozbou však byli hooligans ze sousední Argentiny, kteří se označují názvem Barra Bravas.

Barra Bravas (Statečné gangy) jsou zvláštním př́ípadem chuligánů. V Argentině se začali formovat již v 50. letech 20. století a nyní představují vrstvu, která v evropském prostředí nemá obdoby. Jedná se o násilné organizované gangy, které jsou součástí jednotlivých klubů. Díky nastavení argentinských zákonů, kdy kluby musejí být občanským sdružením, mají členové Barra Bravas velký vliv a jsou kluby přimo podporováni (občerstvení, pyrotechnika, vlajky či dokonce finance). Přestože jsou tyto gangy spojené s fotbalovými kluby, výčet jejich aktivit je širší. Barra Bravas stojí za násilnostmi na stadionech, bitkami fanoušků a různými výhružkami. Stejně tak ale obchodují s drogami a zbraněmi, zastřešují nelegální sázky anebo například prodávají suvenýry a občerstvení. Stát se členem Barra Bravas je tak prestižní záležitostí. Členové se totiž těší respektu ostatních a mají určitá privilegia. Především pro obyvatele chudinských slumů je zapojení se do kriminálních struktur a páchání násilí jedinou možností, jak dosáhnout úcty a financí (Hooligans 2010, Guardian 2011) .

\subsection{Hrozba kybernetických útoků}

Dle definice Ministerstva vnitra České republiky zahrnují kybernetické hrozby a informační kriminalita širokou škálu negativních fenoménů různého stupně závažnosti, ke kterým dochází v prostředí informačních technologií - od kybernetické špionáže, hackerství a DDoS útoků, přes stále častější internetové podvody a krádeže (ohrožení internetového bankovnictví, krádeže dat z kreditních karet, falešné e-shopy, zneužívání osobních údajů atd.) a další formy kriminálních 
či nežádoucích aktivit (šiření dětské pornografie, prodej drog na internetových tržištích a praní špinavých peněz s pomocí virtuálních měn, stalking, internetová šikana, spam atd.) až po projevy extremismu a zneužívání internetu k teroristickým aktivitám a propagandě (včetně např. zveřejňování návodů na konstrukci výbušnin atd.) (Ministerstvo vnitra ČR 2014).

Za posledních několik dekád prošla Brazílie (podobně jako další země) digitální revolucí. Počet uživatelů chytrých telefonů a internetu rychle rostl a zasáhl všechny oblasti lidské činnosti. Podle údajů serveru internetworldstats.com bylo na konci roku 2013 v Brazílii připojenu k internetu již více než $54 \%$ obyvatel. Od roku 2000 do roku 2013 stoupl v Brazílii počet uživatelů internetu o více než $2000 \%$.

S nárůstem uživatelů internetu bylo potřeba i vytvoření institucí a vzdělaných pracovníků, kteří by se v tomto prostředí dokázali orientovat. Jak se digitalizace šírila, objevovala se čím dál častěji i negativa spojená s užíváním internetu (Diniz, Muggah, Glenny 2014).

Brazílie byla jednou z prvních zemí, které zavedly elektronické finanční systémy již v 80. letech. Aktuálně využívá finančních on-line transakcí přibližně tři čtvrtiny Brazilců. Brazílie má v současné době jedny $\mathrm{z}$ největších trhů $\mathrm{v}$ oblasti výpočetní techniky, mobilních sítí, telefonů a sociálních médií na světě. Takto obrovské trhy spojené s nedostatečnou ochranou a kontrolou ze strany státu však lákají kybernetické útočníky. Hackeři se nejdříve zaměřovali na útoky proti webovým stránkám. Po roce 2003 se však začali zajímat i o jejich uživatele a s rostoucí profesionalitou hackerů rostl i počet útoků na banky a další instituce. Například v roce 2011 způsobili hackeři bankám škodu ve výši 1,5 miliardy dolarů. A v roce 2012 bylo dle Abdenurové (2014) v zemi zaznamenáno přes 460000 tisíc počítačových útoků. Brazílie tak před mistrovstvím světa musela čelit několika závažným hrozbám (OSAC Assessment 2014, Fortinet 2014).

Ministerstvo zahraničí Spojených států amerických jmenovalo několik nejzávažnějších. První takovou hrozbou bylo vytváření škodlivého malwaru, který byl určen k napadení osobních počítačů a získání osobních údajů a byl nejčastěji širren skrze aplikace, které byly tematicky zaměřeny na MS. Typickým prríkladem jsou údaje o kreditních kartách a internetovém bankovnictví. Přestože brazilské banky a instituce investovaly do zabezpečení, některé podniky a uživatelé počítačů tak nečinili (nepoužívali antivirové programy nebo neinstalovali aktualizace). Dostatečnou ochranou proti útoku malwaru je přitom používání aktuálního softwaru, základním problémem však je, že podle odhadů běží více jak polovina počítačů na nelegálních kopiích, tudíž nemá príistup k požadovaným aktualizacím. Častou metodou, jak získat data uživatele, je i tzv. phishing. Rozesílán je většinou formou emailů, které imitují různé organizace. Např́ílad e-mail, který na první pohled vypadá, jako by byl z banky, a žádá zadání vstupních údajů. E-mail však není poslán z banky a snaží se jen získat informace. Druhou nejčastější metodou je využivání webových stránek, které se mají zaměnit za ty oficiální. Stránka na první pohled vypadá shodně, liší se jen v detailech. Ochranou proti těmto podvodným praktikám je především obezřetnost uživatele. E-maily jsou často psány nespisovně či jinak nesprávně. Ztrátě lze předejít i kontrolou odesílatele, který se od údajů oficiální banky liší. Před a během šampionátu se podvodné e-maily snažily imitovat bankovní instituce či portály prodávající vstupenky.

Jako další hrozba byl označen „hacktivismus“ čili skupinové útoky. Nejznámější „,hacktivistickou“ organizací je hnutí Anonymous. V Brazílii byla největší hrozbou samozvaná odnož celosvětového hnutí Anonymous s názvem Anonymous Brazil, která se rozhodla upozornit na problémy spojené s násilnou kriminalitou nebo dětskou prostitucí. Zároveň upozorňovala i na nedostatek jídla a následné hladovění části obyvatel či situaci ve vyloučených lokalitách. Pozornosti neunikla ani policejní brutalita. Hackeři z Anonymous dokonce zveřejnili video, kde se k situaci v Brazílii vyjadřují.

Uskupení Anonymous využívá především DDoS útoků, zjednodušeně se jedná o zahlcení internetového cíle (webové stránky, služby) požadavky nebo daty, což vede k následné nefunkčnosti daného cíle pro ostatní uživatele.

Rizikové bylo i využívání on-line obchodů se vstupenkami za výrazně nižší ceny. Tyto stránky většinou obsahovaly viry anebo se opět snažily o získání osobních údajů. Stejná míra nebezpečí 
ale číhala i v nezabezpečených Wi-Fi hotspotech. Návštěvníci, kteří se nedostali na zápas přímo, chtěli často sledovat utkání alespoň on-line, a k tomu často využívali nezabezpečené sítě Wi-Fi. Hackeři ale mohou skrze tyto sítě sledovat všechna data, která jimi projdou. Znovu je tu riziko ztráty osobních údajů, například uživatelských hesel, e-mailů apod. (Fortinet 2014).

Další hrozba se váže $\mathrm{k}$ již zmíněným sociálním nepokojům, které Brazílii před mistrovstvím světa ve fotbale zachvátily. Prostředí internetu a sociálních sítí se stalo důležitým prostředím pro seskupování lidí a organizování následných demonstrací. Symbolem odporu se staly především dva slogany, které se objevovaly na sociální síti Twitter - \#OpBoicoteACopa (Operace bojkot poháru) a \#NaoVeiTerCopa (Žádný pohár nebude).

Brazilské úřady se také musely připravit na eventuální útok na průmyslové kontrolní systémy. $\mathrm{Na}$ takovéto útoky už je třeba schopných hackerů a jejich cílem se stávají rozvodné elektrické sítě či dopravní značení. Například hackeři hlásící se $\mathrm{k}$ Anonymous však veřejně deklarovali, že jejich snahou není poškodit zdraví a majetek civilistů. V Brazílii ale hrozí jiná zdravotní nebezpečí.

\subsection{Zdravotní rizika}

Ačkoliv se bezpečnostní a strategická studia nevěnují přímo otázkám zdraví, při snaze o co největší pokrytí tématu hrozeb šampionátu je $\mathrm{v}$ práci zařazena část, která částečně uvádí čtenáře do problematiky. Mistrovství světa ve fotbale je akcí, která do Brazílie přitáhla ohromné množství lidí ze všech koutů světa. Brazílie předběžně odhadovala, že zemi navštíví na 600000 zahraničních turistů. Fotbalová utkání měla navíc přilákat i přibližně 3 miliony Brazilců z různých částí země. Hlavními hrozbami doprovázejícími shromažd’ování obrovského počtu lidí byly přenosné choroby, které by v takovém prostředí mohly brzo přerůst v epidemie. Př́ípadnými ohnisky vzniku mohly být například místa, kde se hromadně prodávalo občerstvení a nápoje (pouliční stánky, fast foody atd.). Riziko s sebou neslo i větší užívání drog a alkoholu během šampionátu. Dalším faktorem, který mohl ohrozit zdraví účastníků, především turistů, bylo specifické podnebí a podmínky, které panovaly v jednotlivých městech a vzájemně se od sebe lišily.

Zpráva Evropského střediska pro prevenci a kontrolu nemocí uvádí několik hlavních oblastí, které mohly být v Brazílii potenciálně zdraví nebezpečné.

- Onemocnění s původem v potravinách či vodě - Jedná se hlavně o nemoci, jako je salmonela nebo escherichia coli. Lidé se jimi mohou nakazit po pozření nedostatečně upravených potravin anebo po potravinách, s kterými nebylo nakládáno s dostatečnou hygienou.

- Podle Světové zdravotnické organizace je v Brazílii i středně vysoký výskyt hepatitidy typu $A$, oproti tomu cholera se v Brazílii nevyskytuje od roku 2005.

- Přenosné choroby - Nejtypičtější nemocí tohoto typu je v Brazílii komáry přenášená horečka dengue. Její výskyt se mění podle ročních období a oblastí země. V Brazílii se též může vyskytovat malárie či žlutá zimnice.

- Tuberkulóza - vysoký výskyt především v chudinských čtvrtích

- HIV/AIDS

- Ostatní pohlavně přenosné choroby

- Chřipka a virová onemocnění

- Ostatní nebezpečí - autonehoda, bleskové povodně atd.

Přestože se Brazílii povedlo vymýtit některé nemoci, které jsou v ostatních zemích regionu obvyklé (spalničky, zarděnky), stále jsou některé nebezpečné nemoci přítomné (Risk Assessment 2014).

Vysokou měrou se na tom podepisuje i stav současného brazilského zdravotnictví. Př́istup k zdravotním službám je v Brazílii nerovný. Dostupnost nemocnic, léků i kvalitního ošetření se zhoršuje směrem od center velkých měst do rurálních oblastí. Například Ministerstvo zahraničních věcí České republiky absolutně nedoporučuje v případě potřeby ošetření navštěvovat veřejné nemocnice, ale vyhledat pomoc u soukromých zdravotnických zařízení. 
Právě stav zdravotnictví byl jedním z hlavních témat, která doprovázela demonstrace během roku 2013. Lidé si stěžovali na velké výdaje na pořádání sportovních akcí, namísto investic do zlepšení služeb a lékařské péče.

\section{Opatření vedoucí $k$ zajišstění bezpečnosti šampionátu}

Pro zajištění bezpečnosti během mistrovství světa ve fotbale a olympijských a paralympijských her byl brazilskou prezidentkou Roussefovou v roce 2011 založen Úřad pro bezpečnost velkých akcí (dále jen SESGE) pod gescí Ministerstva spravedlnosti. Hlavním úkolem bylo spojit veškeré složky, které se na plánování a zajištění veřejné bezpečnosti budou podílet, pod jedno velení. Vzniklo tak Integrované řídící a kontrolní centrum (CCIC) s pobočkami ve všech hostitelských městech a hlavním sídlem ve městě Brasilia, kde se vyhodnocovaly informace ze všech těchto poboček, mezinárodních databází i celkem 28 mobilních jednotek CCIC, jež byly rozloženy po celém území Brazílie (OSAC Assessment 2014).

Na zajištění bezpečnosti se podílelo i brazilské ministerstvo obrany. Brazilská armáda se dělí na tři základní útvary: námořnictvo, vzdušné síly a pozemní síly. Jejich koordinace byla zajištěna generálním štábem (EMFCA). Brazilská armáda pracovala pod nově založeným Koordinačním centrem pro obranu (CCDA) v Riu de Janeiru.

Policejní a armádní složky každého brazilského státu byly odpovědné za kontrolu okolí stadionů a přilehlých ulic, letište, př́stavů a jednotlivých pořadatelských měst. Záměrem SESGE bylo zajištění integrace, organizace a propojení lidských a materiálních zdrojů dohromady na federálních, státních i lokálních úrovních (např. propojení sledovacích technologií, monitoring sociálních sítí atd.). Zároveň měl SESGE efektivně řídit veškeré veřejné instituce, které se pohybovaly v oblasti bezpečnosti. SESGE však nepůsobil jen uvnitř Brazílie, ale spolupracoval i s jinými státy či mezistátními organizacemi. Po skončení letních olympijských a paralympijských her v Riu de Janeiru v roce 2016 SESGE ukončí svou činnost (U. S. Commercial Service 2014).

Na plánování a provádění bezpečnostních opatření se tedy podílely především následující složky:

- Ozbrojené síly - Během šampionátu se armáda zaměřila na deset strategických oblastí. 1) Vzdušný prostor; 2) Ochrana strategických struktur (př. elektrárny, zdroje vody); 3) Kontrola moří a řek; 4) Ochrana hranic státu; 5) Ochrana muničních skladů; 6) Kybernetická bezpečnost (CDCiber); 7) Ochrana proti chemickým, biologickým, radiologickým a nukleárním útokům; 8) Prevence a boj proti terorismu; 9) Používání helikoptér; 10) Pohotovostní síly.

- Federální policie - Jejich úkolem byla ochrana hranic, řešení problémů s imigrací, nadnárodní zločin a terorismus.

- Federální dálniční policie - Zajištovala bezpečnost na dálnicích a zajištovala bezpečný průjezd zvlášt důležitým osobám.

- Zpravodajská služba (ABIN) - Zaměřovala se na analýzy a mezinárodní spolupráci v oblasti protiteroristických opatření.

- Vojenská policie - Brazilská vojenská policie je součástí složek veřejné bezpečnosti a je zodpovědná za udržování veřejného pořádku. Během mistrovství světa měla na starost kontrolu turistických oblastí, ochranu hotelů a oficiálních událostí MS. Současně byla složkou, která by řešila případné problémy na stadionech, za jejichž bezpečnost standardně ručila FIFA.

- Civilní policie - Jedná se o základní složku bezpečnosti, která má na starosti vyšetřování trestných činů.

- Speciální policie pro podporu cestovního ruchu (DEAT) - jedná se o speciální útvar civilní policie, který má na starost kriminalitu páchanou na návštěvnících země (OSAC Assessment 2014, Ministry of Defense 2014).

Na bezpečnost během šampionátu dohromady dohliželo přibližně 170000 vojáků a policistů. V ulicích bylo připraveno 20000 speciálně vycvičených policistů, kteří byli lépe jazykově vybaveni, a měli tak pomáhat turistům. Pro zvládání očekávaných demonstrací bylo vyčleněno 10000 členů 
zásahové policie, kteří byli připraveni ve všech pořadatelských městech, a na bezpečnost v ulicích dohližžely i speciální policejní útvary s modrými barety. Brazílie v rámci opatření využívala i 20 lodí a 60 člunů, vrtulníky či letadla. Bezpečnost vzdušného prostoru nad stadiony pomáhaly zajistit i bezpilotní letouny (např. Hermes 900) a drony. Pro potřeby zásahu na zemi měla Brazílie k dispozici desítky robotů na dálkové ovládání, jejichž úkolem bylo identifikování objektů a osob. Celkové výdaje na bezpečnost se měly pohybovat okolo částky 20 miliard korun (Česká televize 2014a).

Výše zmíněné počty se týkají jen samotné Brazílie a státních složek. V oblasti však působilo i několik set bezpečnostních agentur a zaměstnanci organizace FIFA.

V praxi to znamenalo, že na veřejný pořádek dohližely brazilské státní složky nebo státem najaté bezpečnostní agentury. Bezpečnost na stadionech zajištovala FIFA svými zaměstnanci anebo zaměstnanci najatých bezpečnostních agentur. $V$ případě, že by došlo k vážnějšímu incidentu, byly připraveny i jednotky vojenské policie, které ovšem byly primárně mimo stadion.

\subsection{Opatření proti terorismu}

V Brazílii se nevyskytuje žádná domácí teroristická organizace a země dlouhodobě nevnímala terorismus jako hrozbu, což potvrzovala např́klad absence protiteroristického zákona až do roku 2014. Jak již ale bylo zmíněno, Brazílie se kvůli pořádání akce světového rozsahu mohla stát terčem teroristického útoku, kvůli němuž by mohlo dojít $\mathrm{k}$ velikým ztrátám. Brazílie proto přijala některá opatření a snažila se toto riziko eliminovat.

Terorismem se v Brazílii zabývá několik institucí, které se dělí podle jejich působnosti. Jedná se o zpravodajskou službu (ABIN), brazilskou federální policii a její protiteroristickou divizi (DAT) a Taktický operační tým (COT). Na státní úrovni pak působí především vojenská policie s jejími Speciálními policejní prapory (BOPE) a civilní policie a její Divize speciálních operací (DOE). Tyto jednotky prošly speciálním tréninkem a př́pravou na krizové situace, jaké představují útoky chemickými či biologickými zbraněmi. Měly též moderní vybavení jako motorové čluny a lodě, přenosné rentgeny, dálkově ovládané roboty na vyhledávání a zneškodňování bomb, ale i neletální zbraně (např. slzný plyn, kouřové granáty či gumové projektily) (OSAC Assessment 2014).

Co se týče opatření na ochranu před „osamělým vlkem“, kterého se brazilské úřady obávaly nejvíce, šlo především o důsledný monitoring jedinců, kteří sice nepatří k žádné teroristické buňce, ale jsou příznivci radikálního výkladu náboženství či džihádu. Odhaleno bylo několik plánů na útoky, ovšem nejednalo se o žádné velké hrozby i díky tomu, že byly odhaleny včas (Brics post 2015).

Další ochranou proti „osamělým vlkům“ byla i další opatř̌ení, která se týkala veřejné bezpečnosti. Jde například o přitomnost většího množství policistů a vojáků v ulicích, kteří dohlíželi na pořádek a prrípadné nebezpečí by dokázali včas odhalit. Příletu radikalizovaných jedinců měla například zabránit mezinárodní spolupráce, jíž se tato práce zabývá více $\mathrm{v}$ části věnované opatřením vůči chuligánství.

Předejít problémům s narkoterorismem měly některé akce brazilské policie v chudinských čtvrtích. Těm se kvůli propojení narkoterorismu, organizovaného zločinu a kriminality věnuje práce $\mathrm{v}$ následující kapitole.

\subsection{Opatření proti kriminalitě}

Brazílie si byla vědoma, že dlouhodobě vysoká kriminalita je rizikem nejen pro nadcházející šampionát, ale i pro běžný život. Již v roce 2008 tak vznikl program Pacifikace favel, který měl vyčistit největší zdrojové oblasti kriminality - slumy. Změnil se způsob, jakým Brazílie k „čištěni“ favel přistupovala. Akce probíhající před programem Pacifikace favel byly spíše nárazové a neměly delší účinnost. S programem však přišla změna a strategičtější přístup k favelám. Po jejich obsazení zde zůstaly činné policejní složky $\left(\mathrm{UPP}^{1}\right)$ a začaly se zavádět standardní služby, které

\footnotetext{
${ }^{1}$ Unidades de Polícia Pacificadora - jsou speciální složkou v rámci vojenské policie. Po obsazení favel dohližejí na pořádek v ulicích. Kvůli problémům s policejní korupcí a brutalitou jsou útvary UPP tvořeny novými rekruty, kteří nejsou součástí zaběhnutých praxí (Riechers 2013).
} 
byly dřive v těchto chudinských částech nemyslitelné (například stavba škol). Favely se měly stát rovnocennými součástmi měst (WOLA 2011).

Victoria Riechers (2013) hovoří o 3 fázích pacifikace favel. V první fázi jde o taktickou intervenci, která je v režii speciálních jednotek BOPE. Které obsadí prostor slumu za použití těžké techniky. Druhou fází je stabilizace. Tato fáze trvá přibližně 100 až 150 dní, během nichž je celá favela pod kontrolou bezpečnostních sborů. Vojenská policie zrrídí policejní stanice, které symbolicky nahrazují drogové dealery jako vůdce slumů. Poslední fází je konsolidace, tedy příchod jednotek UPP a zapojení favel do normálního způsobu života (Riechers 2013).

Boj s kriminalitou je v Brazílii zajištován především federální a civilní policií.

V roce 2011 proběhla operace s názvem Mírový šok, která měla za cíl obsadit největší slum jménem Rocinha v Riu de Janeiru. Akce se zúčastnilo až dva tisíce vojáků námořní pěchoty a policistů, kterým se za použití helikoptér i tanků povedlo obsadit území, kde žije přes 100000 lidí, a to bez ztrát na životech. Policie do tohoto slumu vstoupila po 30 letech, před tím byl zcela ovládán drogovými kartely (Český rozhlas 2011).

V následujících letech proběhlo ještě několik podobných akcí, které byly součástí boje proti kriminalitě a drogovým kartelům. Dalším příkladem může být akce $\mathrm{z}$ doby těsně před zahájením mistrovství světa. Opět se jednalo o slum v Riu de Janeiru. Cílem bylo obsazení a zabezpečení favely Maré, ležící na severu města v blízkosti letiště Galeao, kam mělo přilétat velké množství návštěvníků. Scénář byl podobný jako u akce Mírový šok, policejní a vojenské jednotky obsadily slum během několika desítek minut. Zároveň zajistily zbraně a několik desítek kilo marihuany společně s několika dealery. Nicméně většina dealerů drog opustila slum ještě před touto akcí. Favela Maré se stala 39. zajištěnou favelou od začátku programu Pacifikace (Reuters 2014a, Česká televize 2014b).

I přes snahu brazilských úřadů však země zůstává pro turisty nebezpečná. Brazílie si toho byla vědoma a před mistrovstvím světa vydala veřejné př́ručky pro návštěvníky, jak minimalizovat možnost, že se stanou obětí trestného činu, případně jak se chovat poté. Jedním z opatření proti kriminalitě tak bylo včasné informování návštěvníků a snaha minimalizovat toto riziko vhodným chováním turistů. Na situaci v Brazílii upozorňovala média i jednotlivé státy. Například české ministerstvo zahraničních věcí na svých stránkách doporučuje dodržování některých zásad - naprríklad: stále si hlídat vlastní zavazadla, nenosit viditelně šperky, řetízky nebo elektroniku (kamery, fotoaparáty), nemít u sebe vysokou hotovost, vyvarovat se nebezpečným čtvrtím a místům, být obezřetný a nepoutat pozornost atd. V prŕípadě, že se turista stane obětí trestné činnosti, zní rada následovně: neodporovat a vydat vše, co útočníci žádají. Často jsou totiž ozbrojeni a nebezpeční. Trestné činy na turistech a návštěvnících řeší v Brazílii speciální útvar civilní policie s názvem Speciální policie pro podporu cestovního ruchu (DEAT).

I u kriminality platí, že její prevencí byl velký počet policejních a vojenských složek v ulicích a na strategických místech. Dle údajů brazilské vlády připadal jeden policista na každých 50 lidí $\mathrm{v}$ ulicích. Na důležitých místech se nacházely rozšířené hlídky a k dispozici měly motocykly a automobily. Ze vzduchu navíc byla situace kontrolována vrtulníky (World Cup Portal 2012).

\subsection{Opatření proti sociálním nepokojům a demonstracím}

Jako u předešlých oblastí i zde platí, že základním preventivním opatřením byl větší počet bezpečnostních složek v ulicích. Ke zvládání předpokládaných demonstrací mělo přispět i speciální školení odpovědných brazilských policistů americkou FBI, které se uskutečnilo v Belo Horizonte $\mathrm{v}$ roce 2014. To mělo připravit zasahující policisty na možné problémy během nepokojů a také zajistit, aby byla dodržována základní lidská práva demonstrantů (CNN 2014).

Zvládání demonstrací má v Brazílii na starosti vojenská police. V souvislosti s pořádáním mistrovství světa ve fotbale a olympijských her však byla v roce 2013 vytvořena speciální jednotka BPGE (Policejní útvar pro velké události), která byla pověřena zvládáním demonstrací a sociálních nepokojů. Vybavení této jednotky se skládá z nejnovějších materiálů a technologií a její členové si svým zjevem vysloužili označení „RoboCops“ či „Darth Vaders“. BPGE má k dispozici neprů- 
střelné několikavrstvé ochranné vesty s chrániči ramen, hrudníku i zad, střelné zbraně, paralyzéry i obušky. Výzbroj těchto policistů navíc odolá teplotě až $430{ }^{\circ} \mathrm{C}$. Důvodem, proč si jednotky vysloužily své přezdívky, jsou speciální moderní plynové masky, které jsou odolné až do téměř $1000^{\circ} \mathrm{C}$ a zároveň se nezamlžují (Latin post 2014).

Dalším moderním prvkem výbavy policistů byly tzv. „chytré brýle“, které v sobě mají zabudovanou kameru na snímání obličejů lidí v davu. Obrázek je ihned odeslán do Kontrolního centra (COR) v Riu de Janeiru a je srovnán s databází známých zločinců. Pokud najde shodu, okamžitě informuje př́islušné policisty. Centrum COR sbírá informace o stavu sítí, záznamy z pouličních kamer, satelitní snímky atd. Informace jsou poskytovány COR skrze uzavřený okruh. COR sbírá a vyhodnocuje získaná data, ale jejím primárním cílem není zasahovat proti demonstracím a nepokojům. Řešení demonstrací mělo na starosti Integrované řídící a kontrolní centrum (CCIC) s hlavním sídlem ve městě Brasilia a mobilními centry ve všech 12 pořadatelských městech (Latin post 2014).

O mobilních jednotkách CCIC již byla řeč v úvodu kapitoly o bezpečnostních opatřeních. Jednalo se o 28 vozidel, které dodala na žádost SESGE společnost Radwin. Mobilní jednotky typu Radwin 5000 PtMP dokázaly do integrovaného systému posílat živé přenosy kamer, hlasu i dat a byly rozestavěny na strategických místech jako letiště či centra měst nebo u fotbalových stadionů. Společně s 28 vozidly dodala společnost Radwin i 60 základních stanic, s umístěním taktéž na strategických místech, které zlepšovaly komunikaci mezi mobilními jednotkami a centrálou CCIC (Radwin 2014).

\subsection{Opatrení proti diváckému násilí a chuligánství}

I v př́ípadě chuligánství a diváckého násilí lze považovat za nejzákladnější opatření brazilské vlády navýšení počtu bezpečnostních složek v ulicích. Důležité je ale rozdělit projevy chuligánství a diváckého násilí podle jejich místa. Jakékoliv násilné projevy během zápasů měla totiž na starosti primárně organizace FIFA. Postup, jak FIFA zajištuje bezpečnost na stadionech, lze volně stáhnout na webových stránkách organizace. Až v případě většího konfliktu byly u stadionů připraveny jednotky vojenské policie, které měly př́ipadné problémy zvládnout.

Co se týče chuligánství, mají pořadatelské státy těžkou pozici. Při zajištění bezpečnosti se musejí vypořádat s domácí hooligans scénou stejně jako s chuligány, kteří do země chtějí prricestovat. Při pořádání velkých mezinárodních sportovních akcí jsme byli v posledních letech svědky přistupu, který se snaží problémům s chuligánstvím předcházet. Velký důraz je kladen na mezinárodní spolupráci a na zachycení potenciálních hools před vstupem do země. Brazílie v tomto ohledu nebyla výjimkou a díky nadnárodní spolupráci se ji podařilo zamezit vstupu do země některým problémovým lidem. Místem, kde se informace sbíhaly a vyhodnocovaly, bylo opět Integrované řídící a kontrolní centrum (CCIC).

Během pořádání mistrovství světa pozvala brazilská vláda i zástupce bezpečnostních složek všech účastníků, aby pomáhali dohližet na bezpečnost během utkání svých národních týmů. Tito zástupci nebyli ozbrojení a jejich úkolem bylo i dělat zprostředkovatele v př́padě problému mezi fanoušky a bezpečnostními složkami (OSAC Assessment 2014).

Největší strach měli organizátoři z fanoušků Barra Bravas, pocházejících z Argentiny; tomu byla také uzpůsobena bezpečnostní opatření. Chuligáni Barra Bravas způsobili v minulosti již několik incidentů - např. pobodání anglických fanoušků během MS v Mexiku v roce 1986 nebo bitky na předcházejícím mistrovství světa $\mathrm{v}$ Jihoafrické republice. Podle zpráv brazilských úradů navíc většina fanoušků Argentiny neměla zakoupené jízdenky a očekávalo se tak, že se budou ve velkých počtech shromažd’ovat v okolí stadionu. Díky výše zmíněné mezinárodní spolupráci se brazilským bezpečnostním složkám podařilo získat seznam více jak 2000 nebezpečných chuligánů, někteří nebyli do země puštěni a někteří byli v zemi zachyceni a následně deportováni (Reuters 2014b).

Argentinské národní mužstvo se posléze dostalo až do finále, které provázela největší opatření týkající se jednoho zápasu během celého šampionátu. Podrobněji se jim studie věnuje v části věnované průběhu turnaje. 


\subsection{Opatření proti kybernetickým hrozbám}

O kybernetickou bezpečnost se staraly některé soukromé bezpečnostní agentury, ale především Centrum kybernetické bezpečnosti (CDCiber), které podléhalo ministerstvu obrany. CDCiber bylo založeno $v$ roce 2010 a zajímalo se o ochranu strategických institucí a úzce spolupracovalo s Integrovaným řídícím a kontrolním centrem (CCIC) (Linha Defensiva 2012).

Ještě před samotným zahájením se Brazílie stala terčem kybernetických útoků. V únoru roku 2014 byl zaznamenán nárůst infikací jednoho druhu malwaru. Jednalo se o napodobeninu populární aplikace WhatsApp. Za několik hodin, kdy byl malware „V oběhu“, se nakazilo na 400 počítačů. CCIC ho však rychle identifikovalo a zneškodnilo. Malware po instalaci sbíral osobní data a hesla z prohližeče Windows Internet Explorer (Tiger Security 2014).

Druhý útok byl cílený na Ministerstvo zahraničních věcí Brazílie a odehrál se jen několik dní před zahájením šampionátu. Zaměstnancům ministerstva bylo rozesláno přes 600 phishingových e-mailů a nakaženo bylo přes 50 účtů. E-mail udával odkaz na falešnou stránku, která měla být vytvořena pro interní zaměstnance, a žádal přihlášení pomocí osobních údajů. Tyto údaje poté útočníci použili k nahlédnutí do soukromých i pracovních emailů zaměstnanců. Ministerstvo zablokovalo přistup k e-mailům hned, jak se o útoku dozvědělo. Údajně neunikla žádná důležitá data (Tiger Security 2014).

I přes snahu brazilských orgánů a bezpečnostních firem věnujících se kybernetickým hrozbám se nepodařilo zastavit všechny útoky. Společnost Trend Micro, která spolupracovala na zajištění bezpečnosti v kyberprostoru během šampionátu, například na svých stránkách zveřejňovala seznam podvodných stránek a aplikací, stejně tak upozorňovala na „phishingové“ e-maily. Nicméně základním bezpečnostním opatřením mělo být správné chování uživatele internetu, který dokáže sám rozpoznat základní nebezpečí nebo podezřelé stránky a programy. Úřady taky výrazně doporučovaly použivat legální kopie operačních programů a antivirové softwary (Trend Micro 2014).

\subsection{Opatření před zdravotními riziky}

V reakci na špatnou situaci ve zdravotnictví a následné sociální nepokoje prezidentka Rousseffová spustila kampaň Mais Medicos („Více doktorü“), během které mělo do země přijít pracovat přibližně 13000 nových doktorů, a to především z Kuby (OSAC Assessment 2014).

Přes původní záměr získat tento počet lékařů se tohoto čísla nedosáhlo. Přesto kampaň počty pracovníků ve zdravotnictví zvýšila.

Návštěvníci Brazílie také měli dbát na své zdraví a využívat očkování. Druh očkování se lišil podle toho, odkud turisté pocházeli. Naprríklad návštěvníkům z Evropské unie bylo doporučeno očkování proti dětské obrně, tetanu, černému kašli, příušnicím a zarděnkám. Návštěvníci si také měli dávat pozor na hepatitidy typu A a B, jelikož jsou v Brazílii častější než v Evropě. Turisté by také měli brát zřetel na to, že v Brazílii jsou oblasti, kde se vyskytuje žlutá zimnice. Nebezpečím pro cizince byla i horečka dengue. Nejlepší ochranou proti všem nemocem bylo očkování a případná konzultace s praktickým lékařem a státními orgány věnujícími se zahraničním destinacím (Risk Assessment 2014).

\section{Průběh šampionátu}

Mistrovství světa se odehrálo v období mezi 12. červnem až 13. červencem roku 2014 v celkem 12 městech Brazílie. Z kvalifikace se na něj svými výkony probojovalo 32 národních mužstev, reprezentace České republiky se do finálového turnaje nekvalifikovala.

Zahájení turnaje doprovázely menší střety s policií ve městě Sao Paulo. Policie použila slzný plyn, gumové projektily i ohlušující granáty jako reakci na snahu demonstrantů dostat se na hlavní silnici. Během potyček bylo zraněno 5 lidí (Reuters 2014c).

Menši problémy přinesl zápas mezi Argentinou a reprezentací Bosny a Hercegoviny, kam se snažilo dostat několik argentinských fanoušků bez platné vstupenky. Všichni byli posléze zadrženi policií. K podobnému incidentu došlo i v zápase reprezentací Chile a Španělska. Přibližně 100 př́iznivců Chile se snažilo na stadion dostat skrze tiskové centrum. Po své cestě poničili ma- 
jetek a došlo i ke zraněním. V tomto případě byla nakonec za chování svých fanoušků potrestána chilská fotbalová asociace, která obratem tyto fanoušky penalizovala zákazem vstupu na domácí stadiony, ale i zákazem cestování na zápasy odehrávané mimo území Chile. Zápas mezi Argentinou a Bosnou a Hercegovinou měl však ještě jednu dohru. Policie během zápasu zatkla dva fanoušky Argentiny za údajné rasistické urážky svých protivníků. Případům diskriminace na MS v Brazílii se podrobněji věnuje i report od organizace Fare Network, který je volně dostupný na jejich internetových stránkách (Supporters 2014).

Nejvýraznějším zápasem se pro celou Brazílii stalo semifinálové utkání s Německem. Domácí výběr v něm svému soupeři podlehl vysoce $1: 7$ a to ukončilo jeho naději na výhru v celém turnaji. Reakce brazilské veřejnosti na sebe nenechaly dlouho čekat. Násilnosti se odehrávaly okolo veřejných prostranství, kde se fotbalové utkání odehrávalo, i na oficiálních „Fan festech“. V Sao Paulu neznámý útočník zapálil garáže s vyřazenými autobusy. V Sao Paulu byl mj. vyrabován obchod s elektronikou. K útokům docházelo i v jiných částech země. Jednalo se hlavně o hospodské rvačky a podobně. Ve městě Belo Horizonte, kde se utkání odehrálo, bylo po potyčkách s policií zadrženo 8 lidí, 12 jich bylo zraněno. Policie také očekávala další vlnu násilí po případné provokaci od příznivců Argentiny, kteří hráli semifinále s reprezentací Nizozemska. Ne všechny reakce však byly násilné, někteří fanoušci Německu gratulovali a vyjadřovali úctu (Česká televize 2014c, Český rozhlas 2014).

Největší bezpečnostní akce celého šampionátu se uskutečnila až v jeho závěru. Finálový zápas mezi Německem a Argentinou byl vyhodnocen jako rizikový, především kvůli fanouškům jihoamerické země. Brazílie do té doby bezpečnostní akci takovéhoto rozsahu nezažila. Finále se konalo v neděli 13. července na stadionu Maracanã v Riu de Janeiru. Okolí stadionu bylo uzavřeno již od předešlého dne, do okolí stadionu nebyl umožněn př́istup nikomu, kdo neměl povolení. To se týkalo např́klad i vystupování lidí z MHD na zastávkách v oblasti nebo kontroly pobřeží námořnictvem. Jelikož se jednalo o utkání, kterému přímo na stadionu přihlížely významné osobnosti a vysocí státní představitelé, bylo snahou brazilských úřadů minimalizovat jakoukoliv hrozbu. Do akce se zapojilo téměř 26000 členů bezpečnostních složek. Kapacita stadionu Maracanã je 76000 diváků. V průměru byl tak na každé 3 fanoušky v hledišti jeden člen bezpečnostních sborů. Jednalo se o členy brazilské armády (cca 9300 členů letectva, námořnictva i pozemních sil), civilní policie (15 000 členů, z čehož přibližně 500 členů bylo v utajení) i federální policie, dálniční policie apod. Do akce byli zapojeni i hasiči (1 750) nebo dopravní inspektoři (600). Přímo na stadionu zajištovalo bezpečnost 1600 stewardů (World Cup Portal 2014a).

Důležitým ukazatelem připravenosti Brazílie na pořádání mistrovství světa se stal i fakt, že během celého šampionátu potřebovalo zdravotní ošetření jen přibližně 0,2 \% všech návštěvníků, přičemž se ale původně počítalo s číslem až 10× vyšším. Z 3,4 milionu bylo ošetřeno jen 17042 lidí a z toho ještě naprosté většině lidí stačilo ošetření na místě ( 97 \% zraněných) (World Cup Portal 2014b).

\section{Bezpečnostní odkaz turnaje}

Mistrovství světa ve fotbale 2014 v Brazílii je nejen z hlediska bezpečnosti spojeno s pořádáním olympijských a paralympijských her v roce 2016, a tak je poměrně složité hledat jasný bezpečnostní odkaz, jelikož Brazílie se na tyto akce připravovala jako na celek. O klasickém bezpečnostním odkazu tak lze hovořit až po roce 2016. Mnoho opatření totiž nyní přetrvává, ale zanikne po ukončení olympijských a paralympijských her v roce 2016 (například SESGE). Některé body z typologie Giulianottiho a Klausera lze ale spatřovat už nyní.

$\mathrm{Z}$ bezpečnostních technologií jistě přetrvají kamerové systémy, které byly $\mathrm{v}$ ulicích nově vybudovány. Zůstanou také přijaté zákony jako např́klad zákon o terorismu. Kvůli velké kritice mezinárodního společenství je také možné předpovídat, že se částečně změní policejní postupy naprríklad pro zvládání demonstrací. Policie byla také kritizována za údajné násilí na bezdomovcích a chudých obyvatelích $\mathrm{v}$ centrech velkých měst, které vedlo $\mathrm{k}$ jejich odchodu do jiných městských 
částí. To připomíná situaci v Pekingu před olympijskými hrami v roce 2008 a jedná se o čtvrtý bod typologie.

Speciálním případem je pak vyklízení favel, které probíhalo od roku 2008. To totiž zahrnuje hned několik bodů zmiňované typologie. Pátý bod, tedy změnu v mezilidských a sociálních vztazích vyjadřuje přístup obyvatel favel $\mathrm{k}$ jednotkám UPP. Policie si získala zpět své postavení a lidé z favel jsou jí za to vděční a znovu se cítí bezpečně. A s vyklízením favel je spojen také bod 6, jenž zmiňuje samotnou rekultivaci chudinských čtvrtí - stavbu škol, policejních stanic atd.

\section{ZÁVĚR}

Předkládaná případová studie si kladla za cíl zanalyzovat bezpečnostní politiku během Mistrovství světa ve fotbale 2014 v Brazílii. Práce se snažila vyjmenovat největší hrozby a rizika, která doprovázela tuto velkou sportovní událost, a zároveň popsat opatření a strategické prrístupy k zajištění bezpečnosti během turnaje.

Brazílie se musela vypořádat $\mathrm{s}$ bezpečnostním problémem, kdy se fanoušci, kteří přicestovali do země, stávali v podstatě zároveň jak referenčním objektem, tak i zdrojem hrozeb. Dále se Brazílie musela vypořádat i se situací na domácí půdě. Vysoká kriminalita, policejní brutalita, porušování základních lidských práv, špatný stav zdravotnictví a socioekonomické problémy aj. byly spouštěčem nepokojů a demonstrací, které se staly nejvíce vnímanou hrozbou. Nakonec se tak obavy nenaplnily a během šampionátu nedošlo $\mathrm{k}$ větším narušením pořádku. Do jisté míry za to mohou bezpečnostní opatření a strategické postupy, kterými byl celý šampionát doprovázen.

Nejvýznamnějším krokem k zajištění veřejného pořádku bylo dočasné vytvoření Úřadu pro bezpečnost velkých akcí (SESGE) a následné zbudování center jako CCIC nebo CCDA. Tato centra shromažd'ovala a vyhodnocovala informace $\mathrm{z}$ celé země a zároveň využívala i mezinárodních databází. To, že se Brazílie připravila opravdu důkladně, dokládá i vytvoření speciálních policejních složek jako BPGE, DEAT nebo UPP. Brazílie se své problémy nesnažila skrývat a návštěvníky dopředu připravovala na možná rizika, která jim při pobytu v zemi hrozila. To dokládá např́klad distribuce letáků s doporučeními a bezpečnostními radami.

Nutno připomenout, že oblast bezpečnosti byla jednou z největších finančních položek při plánování celého šampionátu. Vliv na bezpečnost během šampionátu však mohla mít i povaha občanů této jihoamerické země, pro které bylo mistrovství světa na domácí půdě svátkem, jelikož fotbal milují. $\mathrm{O}$ to větší zklamání v ulicích zavládlo po semifinálové porážce $1: 7 \mathrm{~s}$ reprezentačním výběrem Německa. Po této brazilské tragédii také došlo k nejvýraznějším incidentům, které odrážely rozhořčení fotbalového národa. Nejednalo se ovšem o žádné větší problémy.

Mistrovství světa 2014 v Brazílii lze považovat z hlediska bezpečnosti za vydařené. Pořadatelé se dokázali postarat o zajištění víceméně bezproblémového šampionátu ve všech pořadatelských městech i v zemi s tolika problémy, jako je Brazílie. Jejich práce však nekončí a již nyní se připravují na další sportovní událost světového významu. V roce 2016 bude město Rio de Janeiro hostit letní olympijské hry. Proto se také velké množství rí́dicích center a institucí vytvořilo právě v Riu de Janeiro. Zkoušku v podobě mistrovství světa ve fotbalu Brazilci zvládli a s největší pravděpodobností zvládnou i tuto další bezpečnostní výzvu.

\section{Literatura}

Abdenur, A. E. (2014). Brazil and Cybersecurity in the aftermath of the Snowden Revelations. Multilateral Security Governance. [on-line]. Dostupné z: https://www.academia.edu/8740454/Brazil_and_Cybersecurity_in_the_Aftermath_of_the_ Snowden_Revelations_Konrad_Adenauer_Foundation_2014_

Adorno, S. (2013). Democracy in Progress in Contemporary Brazil: Corruption, Organized Crime, Violence and New Paths to the Rule of Law [on-line]. s. 408-426. Dostupné z: http://www.lifescienceglobal.com/pms/index.php/ijcs/article/ viewFile/1460/850

Boyle, P., \& Haggerty, K. D. (2009). Spectacular security: mega-events and the security komplex. Political Sociology, roč. 3, č. 3, s. 257-274. 
Breslin, W. (2013). Counterterrorism in Brazil: Preparedness to Host the World Cup and Olympics. [on-line]. Dostupné z: http:// papers.ssrn.com/sol3/papers.cfm?abstract_id=2084781

Diniz, G., Muggah, R., \& Glenny, M. (2014). Deconstructing Cyber Security in Brazil: Threats and Responses. Igarapé Institute. [on-line] Dostupné z: http://igarape.org.br/wp-content/uploads/2014/11/Strategic-Paper-11-Cyber2.pdf

Giulianotti, R., \& Klauser, F. (2010). Security Governance and Sport Mega-events: Toward an Interdisciplinary Research Agenda. Journal of Sport \& Social Issues [on-line]. roč. 34, č. 1, s. 49-61. Dostupné z:: http://jss.sagepub.com/content/34/1/49.full.pdf+html.

Hendl, J. (2005): Kvalitativní výzkum: základní metody a aplikace. Vyd. 1. Praha: Portál.

Riechers, V. (2013). Sport Mega-Event Security and Urban Development: Johannesburg and Rio de Janeiro [on-line]. School of International Service. Dostupné z: http://aladinrc.wrlc.org/bitstream/handle/1961/15139/Riechers,\%20Victoria\%20-\%20 Spring\%202013.pdf?sequence $=1$.

Sekot, A. (2008): Sociologické problémy sportu. Vyd. 1. Praha: Grada Publishing.

Smolík, J., Šmíd, T., \& kol. (2010). Vybrané bezpečnostní hrozby a rizika 21. století. 1. vyd. Brno: Masarykova univerzita. Mezinárodní politologický ústav.

Taylor, T., \& Toohey, K. (2007). Impacts of Terrorism-related Safety and Security Measures at a Major Sport Event. Event Management. roč. 9, s. 199-209. Dostupné z: http://www.researchgate.net/publication/29463355_Impacts_of_terrorism_related_safety_and_security_measures_at_a_major_sport_event

Prameny

Fortinet. (2014). Mistrovství světa ve fotbale 2014: Přiležitost pro kybernetický zločin. [on-line]. Dostupné z: http://www. veracomp.cz/uploads/Fortinet/Fortinet_Mistrovstv\%C3\%AD\%20sv\%C4\%9Bta\%20ve\%20fotbale_Zv\%C3\%BD\% C5\%A1en\%C3\%A1\%20kyberkriminalita_Na\%20co\%20si\%20\%20\%20\%20.pdf

Ministry of Defense. (2014). Press Information Kit. [on-line]. Dostupné z: http://www.copa2014.gov.br/sites/default/files/ presskit_mdnacopa_a4_4x0-ingles.pdf

OSAC Assessment. (2014). 2014 FIFA World Cup. [on-line]. Dostupné z: http://world.utexas.edu/io/forms/abroad/OSAC\%20 2014\%20FIFA\%20World\%20Cup\%20Assessment\%20\%282\%29.pdf

Radwin. (2014). Case Study: Radwin Secures the 2014 FIFA World Cup. [on-line]. Dostupné z: http://www.radwin.com/content Managment/uploadedFiles/case-studies/World-Cup-case-study.pdf

Risk Assesment. (2014). Brazil 2014 FIFA World Cup 12 June - 13 July 2014. [on-line]. Dostupné z: http://ecdc.europa.eu/en/ publications/Publications/world-cup-Brazil-mass-gathering-risk-assessment-28-may-2014.pdf

Tiger Security. (2014). Analysis Report: The state of the art of digital guerrilla during 2014 Brazilian World Cup. [on-line]. Dostupné z: https://www.tigersecurity.pro/free_reports/AR_EN20140615_BR_v1.pdf

U.S. Commercial Service. (2014). Public Security during the Games through SESGE. [on-line].Dostupnéhttp://export.gov/ brazil/build/groups/public/@eg_br/documents/webcontent/eg_br_057523.pdf

Publicistické zdroje

BBC. (2013). Brazil protests: Tens of thousands in union-led strikes. [on-line]. 12. července 2013. Dostupné z: http://www.bbc. com/news/world-latin-america-23278321

Česká televize. (2013). „,Fotbalové" protesty v Brazílii: Dva týdny, pět mrtvých a stávka. [on-line]. 27. června 2013. Dostupné z: http://www.ceskatelevize.cz/ct24/svet/232923-fotbalove-protesty-v-brazilii-dva-tydny-pet-mrtvych-a-stavka/

Česká televize. (2014a). Na bezpečnost při MS padne 20 miliard. Hlídat budou ozbrojenci. [on-line]. 11. června 2014. Dostupné z: http://www.ceskatelevize.cz/sport/fotbal/ms-2014/276278-na-bezpecnost-pri-ms-padne-20-miliard-hlidat-budou-ozbrojenci-i-drony/

Česká televize. (2014b). V Riu před fotbalem zpacifikovali už 39. favelu. [on-line]. 31. března 2014. Dostupné z: http://www. ceskatelevize.cz/ct24/svet/268048-v-riu-pred-fotbalem-zpacifikovali-uz-39-favelu/

Česká televize. (2014c). Brazilští fanoušci: Gratulace k postupu i zapálené autobusy. [on-line]. 9. července 2014. Dostupné z: http://www.ceskatelevize.cz/sport/fotbal/ms-2014/279686-brazilsti-fanousci-gratulace-k-postupu-i-zapalene-autobusy/

Český rozhlas. (2011). Největší slum Ria de Janeira má po 30 letech pod kontrolou policie. [on-line]. 14. listopadu 2011. Dostupné z: http://www.rozhlas.cz/zpravy/amerika/_zprava/975760

Český rozhlas. (2012). FIFA trvá na prodeji piva na fotbalovém mistrovství světa. [on-line]. 19. ledna 2012. Dostupné z: http:// www.rozhlas.cz/zpravy/amerika/_zprava/fifa-trva-na-prodeji-piva-na-fotbalovem-mistrovstvi-sveta-v-brazilii--1005945

Český rozhlas. (2014). V Brazílii vypukly po porážce na MS násilnosti, v Sao Paulu hořely autobusy. [on-line]. 9. července 2014. Dostupné z: http://www.rozhlas.cz/zpravy/amerika/_zprava/v-brazilii-vypukly-po-porazce-na-ms-nasilnosti-v-sao-paulu-horely-autobusy--1371986

Hooligans. (2010). Argentina: Historie Barra Bravas. [on-line]. 26. června 2010. Dostupné z: http://hooligans.cz/reports/ foreign/60-jam/763-argentina-historie-barra-bravas

Latin post. (2014). FIFA World Cup 2014: Brazil Spends Almost \$1B on High Tech Security, 'RoboCop'-Style Armored Police. [on-line]. 17. června 2014. Dostupné z: http://www.latinpost.com/articles/15054/20140617/fifa-world-cup-2014-brazil-spends-almost-a-billion-on-high-tech-security-robocop-style-armored-police.htm

Linha Defensiva. (2012). Brazilian Army prepares its CDCiber, the,Cyber Defense Center.' [on-line]. 8. března 2012. Dostupné z: http://www.linhadefensiva.com/2012/05/brazilian-army-prepares-its-cdciber-the-cyber-defense-center/ 
Ministerstvo vnitra České republiky. (2014). Bezpečnostní hrozby. [on-line]. 19. září 2014. Dostupné z: http://www.mvcr.cz/ clanek/bezpecnostni-hrozby-337414.aspx?q=Y2hudW09Mw\%3D\%3D

Reuters. (2014a). Brazilian police backed by troops occupy slum by Rio airport. [on-line]. 30. března 2014. Dostupné z: http:// www.reuters.com/article/2014/03/30/us-brazil-slum-idUSBREA2TOP120140330

Reuters. (2014b). Soccer-Brazil braces for Argentine hooligans during World cup. [on-line]. 9. června. Dostupné z: http://in. reuters.com/article/2014/06/09/soccer-world-hooligans-idINL1N0OM28Q20140609

Reuters. (2014c). Brazil police, protesters clash as World Cup begins. [on-line]. 12. června 2014. Dostupné z: http://www. reuters.com/article/2014/06/12/us-brazil-worldcup-protests-idUSKBNOEN1DD20140612

Sport. (2007). Fotbalové mistrovství světa uspořádá Brazílie [on-line]. 30. řína 2007. Dostupné z: http://www.sport.cz/fotbal/ ostatni/clanek/120022-fotbalove-mistrovstvi-sveta-2014-usporada-brazilie.html

Supporters.cz. (2012). Krátké zprávy [on-line]. 2014. Dostupné z:: http://www.supporters.cz/news.asp?page=4

The Brics post. (2015). Olympics: Brazil anti-terror cell focusing on danger from "lone-wolf". [on-line]. 16. ledna 2015. Dostupné z: http://thebricspost.com/olympics-brazil-anti-terror-cell-focusing-on-danger-from-lone-wolf/\#.VRE0y_15Pi0

The Guardian. (2011). The barra bravas: the violent Argentinian gangs controlling football. [on-line]. 21. srpna 2011. Dostupné z: http://www.theguardian.com/football/2011/aug/21/argentina-football-gangs-barra-bravas

Trend Micro. (2014). 2014 Press Release. [on-line]. 2. června 2014. Dostupné z: http://apac.trendmicro.com/apac/about-us/ newsroom/releases/articles/20140603024542.html

Wola. (2011). Rio de Janeiro's Pacification Program. [on-line]. 5. ledna 2011. Dostupné z: http://www.wola.org/rio_de_ janeiro_s_pacification_program

World Cup Portal. (2012). There will be one pocice officer for every 50 people at world Cup stadiums. [on-line]. 23. listopadu 2012. Dostupné z: http://www.copa2014.gov.br/en/noticia/there-will-be-one-police-officer-every-50-people-world-cup-stadiums

World Cup Portal. (2014a). World Cup final in Rio de Janeiro will have the largest safety operation in Brazil's history. [on-line]. 11. července 2014 Dostupné z: http://www.copa2014.gov.br/en/noticia/world-cup-final-rio-de-janeiro-will-have-largest-safety-operation-brazils-history

World Cup Portal. (2014b). Only 0.2\% of fans needed medical care during the World Cup. [on-line]. 16. července 2014. Dostupné z: http://www.copa2014.gov.br/en/noticia/only-02-fans-needed-medical-care-during-world-cup

\section{Seznam použitých zkratek}

ABIN Zpravodajské služby Brazílie.

AIDS Syndrom získaného selhání imunity.

BBC Britská rozhlasová a televizní společnost.

BOPE Speciální policejní prapory.

BPGE Policejní útvar pro velké události.

CCDA Koordinační centrum pro obranu.

CCIC Integrované rídící centrum.

CDCiber Centrum pro kybernetickou bezpečnost Ministerstva obrany Brazílie.

CNN Kabelová televizní společnost zaměřující se na zpravodajství.

COR Kontrolní centrum v Riu de Janeiru.

COT Taktický operační tým federální policie.

DAT Protiteroristická divize federální policie.

DDoS Druh kybernetického útoku, při kterém dochází k zahlcení cíle požadavky.

DEAT Speciální policie pro podporu cestovního ruchu.

DOE Divize speciálních operací civilní policie.

EMFCA Generální štáb brazilské armády.

$\mathrm{FBI} \quad$ Federální úřad pro vyšetřování.

FIFA Mezinárodní fotbalová asociace.

HIV Virus lidské imunitní nedostatečnosti.

NSA Národní bezpečnostní agentura Spojených států amerických.

OSAC Bezpečnostní rada pro zahraniční záležitosti z Ministerstva zahraničí Spojených států amerických.

OSN Organizace spojených národů.

MS Mistrovství světa.

SESGE Úřad pro bezpečnost velkých akcí.

UPP Policejní pacifikační jednotky.

USA Spojené státy americké.

WOLA Washingtonská kancelár̆ pro Latinskou Ameriku. 